\title{
Penyelesaian Matching Graf Dengan Menggunakan Metode Hungarian dan Penerapannya Pada Penempatan Karyawan di Suatu Perusahaan
}

\author{
Aulia Rahman, Muchammad Abrori, dan Noor Saif Muhammad Musafi \\ Program Studi Matematika, Fakultas Sains dan Teknologi, UIN Sunan Kalijaga, JI. Marsda Adisucipto \\ No. 1 Yogyakarta, Indonesia
}

Korespondensi; Noor Saif Muhammad Mussafi, Email: om_norsa@yahoo.com

\begin{abstract}
Abstrak
Semakin meningkatnya kompetisi global menuntut setiap perusahaan untuk meningkatkan kualitas serta efektifitas kinerja karyawannya yang pada akhirnya diharapkan dapat meningkatkan keuntungan. Penempatan sejumlah $X$ karyawan pada $Y$ pekerjaan dimana masing-masing karyawan mempunyai kompetensi untuk menyelesaikan semua pekerjaan dengan mempertimbangkan beberapa aspek seperti memaksimalkan keuntungan yang diperoleh atau meminimalkan waktu yang diperlukan sebagai akibat dari penempatan $X$ karyawan pada $Y$ pekerjaan dikenal dengan Optimal Assignment Problem. Tujuan dari penulisan ini adalah untuk mencari solusi pada Optimal Assignment Problem dimana aspek yang akan dioptimalkan adalah keuntungan dari penempatan sejumlah $\mathbf{n}$ karyawan pada $n$ pekerjaan yang dapat diperoleh dengan menerapkan konsep teori graf. Dalam hal ini permasalahan dinyatakan sebagai graf bipartit khususnya graf bipartit lengkap berbobot yang menerapkan konsep matching, yaitu pencarian matching sempurna dengan bobot paling optimal. Untuk mencari matching sempurna dengan bobot paling optimal maka dapat digunakan sebuah algoritma optimasi yaitu metode Hungarian. Dengan menggunakan metode Hungarian, diperoleh matching sempurna dengan bobot yang optimal pada graf bipartit lengkap berbobot. Matching dikatakan sempurna jika telah memenuhi semua himpunan simpul $X$ dan $Y$. Matching yang dihasilkan merupakan solusi dari Optimal Assignment Problem yakni memasangkan seorang karyawan tepat satu dengan sebuah pekerjaan dan bobotnya menyatakan keuntungan optimal yang akan diperoleh oleh suatu perusahaan.
\end{abstract}

Kata Kunci: Pencocokan; Masalah penugasan optimal; Metode Hungarian

\begin{abstract}
The increasing global competition requires every company to improve the quality and effectiveness of its employees performance which ultimately is expected to increase profits. The placement of a number of $X$ employees at $Y$ jobs where each employee has the competence to complete all the work by considering several aspects such as maximizing the profit earned or minimizing the time required as a result of the employee $X$ placement on $Y$ work is known as the Optimal Assignment Problem. The purpose of this paper is to find a solution on the Optimal Assignment Problem where the aspect to be optimized is the advantage of the placement of a number of $n$ employees on job $n$ which can be obtained by applying the concept of graph theory. In this case the problem is expressed as bipartite graphs, especially full weighted bipartite graphs that apply matching concepts, ie perfect matching search with the most optimal weight. To find perfect matching with the most optimal weights can be used an optimization algorithm is the Hungarian method. Using the Hungarian method, obtained perfect matching with optimal weight in complete weighted bipartite graphs. Matching is said to be perfect if it has met all the set of node $X$ and $Y$. Matching resulted is a solution of Optimal Assignment Problem that is to pair an employee exactly one with a job and weighted declared the optimal profit to be obtained by a company.
\end{abstract}

Keywords: Matching; Optimal Assignment Problem; Hungarian Method 


\section{Pendahuluan}

Pada dasarnya pencarian matching sempurna dengan bobot maksimal dapat dilakukan dengan mendaftar semua matching sempurna yang berbeda dan menghitung jumlah bobot dari setiap matching sempurna yang diperoleh. Banyaknya matching sempurna yang berbeda pada suatu graf bipartit lengkap dengan $n$ simpul pada masing-masing partisinya adalah sebanyak $n$ ! cara. Sangat tidak efisien jika cara ini digunakan, karena semakin banyak jumlah simpul maka semakin banyak pula matching sempurna yang berbeda. Untuk memudahkan pencarian solusi matching sempurna dengan bobot maksimal, dapat digunakan sebuah algoritma optimasi yaitu metode Hungarian.

Metode Hungarian adalah sebuah algoritma kombinasional untuk optimasi, yang dapat digunakan untuk menemukan solusi optimal dari masalah penempatan karyawan. Versi awalnya, yang dikenal dengan metode Hungarian, ditemukan dan dipublikasikan oleh Harold Kuhn pada tahun 1955. Algoritma ini kemudian diperbaiki oleh James Munkres pada tahun 1957. Oleh karena itu, algoritma ini kemudian dikenal juga dengan nama algoritma KuhnMunkres. Pada penelitian ini akan dibahas metode Hungarian untuk menyelesaikan matching pada graf bipartit lengkap berbobot dimana masalah yang ingin dipecahkan adalah mencari solusi terbaik maksimum pada penempatan karyawan. Keuntungan terbesar penggunaan metode Hungarian adalah kompleksitas algoritmanya yang polynomial. Metode yang digunakan dalam algoritma Hungarian dalam memecahkan masalah sangat sederhana dan mudah dipahami.

\section{Penempatan Karyawan}

Dalam suatu perusahaan sering muncul permasalahan, salah satunya adalah penempatan karyawan (tenaga ahli) pada suatu pekerjaan sehingga penempatan tersebut merupakan penempatan yang optimal. Penempatan tenaga kerja merupakan suatu usaha untuk menyalurkan kemampuan sumber daya manusia sebaik-baiknya dengan jalan menempatkan karyawan pada pekerjaan yang paling sesuai. Pelaksanaan penempatan karyawan yang tepat akan tercipta, manakala kemampuan bekerja dari pegawai sudah sesuai dengan standar yang dibutuhkan untuk melakukan pekerjaan yang dipercayakan kepadanya. Keputusan mengenai penempatan dimaksudkan untuk menempatkan orang yang tepat pada posisi yang tepat.

Penempatan karyawan di suatu perusahaan merupakan salah satu kasus atau permasalahan dalam Optimal Assignment Problem, yaitu merupakan masalah menempatkan sejumlah $n$ pekerja $\left(x_{1}, x_{2}, x_{3}, x_{4}, \ldots, x_{n}\right)$ untuk menyelesaikan $n$ pekerjaan $\left(y_{1}, y_{2}, y_{3}, y_{4}, \ldots, y_{n}\right)$, dalam hal ini jumlah anggota himpunan $X$ maupun $Y$ diasumsikan sama. Dalam masalah Optimal Assignment Problem sejumlah tugas atau assignment akan diberikan kepada sejumlah penerima tugas atau assignee dalam basis satu-satu dengan memperhatikan faktor tertentu seperti memaksimalkan keuntungan atau meminimalkan kerugian. Dalam hal ini yang dimaksud dengan kerugian adalah biaya dan waktu sedangkan yang dimaksud dengan keuntungan adalah pendapatan atau laba. Data pokok pertama yang harus dimiliki dalam menyelesaikan suatu masalah penugasan atau penempatan karyawan adalah jumlah assignee dan jumlah assignment.

Masalah penempatan karyawan dapat dimodelkan dengan menggunakan graf bipartit lengkap berbobot $G=(X, Y)$, dimana $X$ adalah merupakan himpunan karyawan dan $Y$ adalah merupakan himpunan pekerjaan. Sisi-sisi yang menghubungkan antara $X$ dan $Y$ adalah menyatakan hubungan antara karyawan dengan pekerjaan tersebut. Dalam hal ini aspek yang akan dioptimalkan adalah bobot atau peluang penempatan tiap $X$ karyawan pada $Y$ pekerjaan, dimana bobot masing-masing karyawan berbeda karena tingkat keterampilan, pengalaman kerja dan latar belakang pendidikan.

Contoh 1:

Sebuah perusahaan distro mempunyai 5 pekerjaan yang berbeda yaitu:

Pekerjaan I : Memproduksi jaket

Pekerjaan II : Memproduksi rok

Pekerjaan III : Memproduksi hem

Pekerjaan IV : Memproduksi baju safari

Pekerjaan $\mathrm{V}$ : Memproduksi celana panjang. 
Pekerjaan-pekerjan tersebut akan diselesaikan oleh 5 karyawan dimana setiap karyawan mempunyai tingkat ketrampilan, pengalaman kerja dan latar belakang pendidikan yang berbeda. Jumlah produk yang dihasilkan masing-masing karyawan berbeda tiap bulannya, sehingga produktifitas atau keuntungan yang timbul dari berbagai alternatif penugasan dari ke-5 karyawan tersebut juga berbeda. Akan ditentukan solusi agar masing-masing karyawan menepati posisi pekerjaan, sehingga menjadi penempatan paling optimal bagi perusahaan. Jumlah produk yang dihasilkan masing-masing karyawan setiap bulannya dapat dilihat pada Tabel 1 berikut:

Tabel 1 Tngkat ketrampilan pekerjaan masing-masing karyawan.

\begin{tabular}{lccccc}
\hline \multirow{2}{*}{ Karyawan } & \multicolumn{5}{c}{ Pekerjaan } \\
\cline { 2 - 6 } & I & II & III & IV & V \\
\hline Afif & 10 & 12 & 10 & 8 & 15 \\
Bady & 14 & 10 & 9 & 15 & 13 \\
Dzaky & 9 & 8 & 7 & 8 & 12 \\
Faras & 13 & 15 & 8 & 16 & 11 \\
Ghazy & 10 & 13 & 14 & 11 & 17 \\
\hline
\end{tabular}

Penyelesaian:

Untuk menyelesaikan permasalahan di atas, setiap karyawan dan setiap pekerjaan dapat dinotasikan sebagai berikut:

\begin{tabular}{|c|c|c|c|}
\hline$x_{1}$ & $=$ Afif & $y_{1}$ & $=$ Pekerjaan I \\
\hline$x_{2}$ & $=$ Bady & $y_{2}$ & = Pekerjaan II \\
\hline$x_{3}$ & $=$ Dzaki & $y_{3}$ & = Pekerjaan III \\
\hline$x_{4}$ & $=$ Faras & $y_{4}$ & $=$ Pekerjaan IV \\
\hline$x_{5}$ & $=$ Ghazy & $y_{5}$ & $=$ Pekerjaan $\mathrm{V}$ \\
\hline
\end{tabular}

Tabel 1 dapat diilustrasikan dengan graf bipartit $K_{5,5}$ berbobot dengan partisi himpunan simpul $X=\left\{x_{1}, x_{2}, x_{3}, x_{4}, x_{5}\right\}$ dan $Y=\left\{y_{1}, y_{2}, y_{3}, y_{4}, y_{5}\right\}$ seperti pada gambar 1 berikut ini:

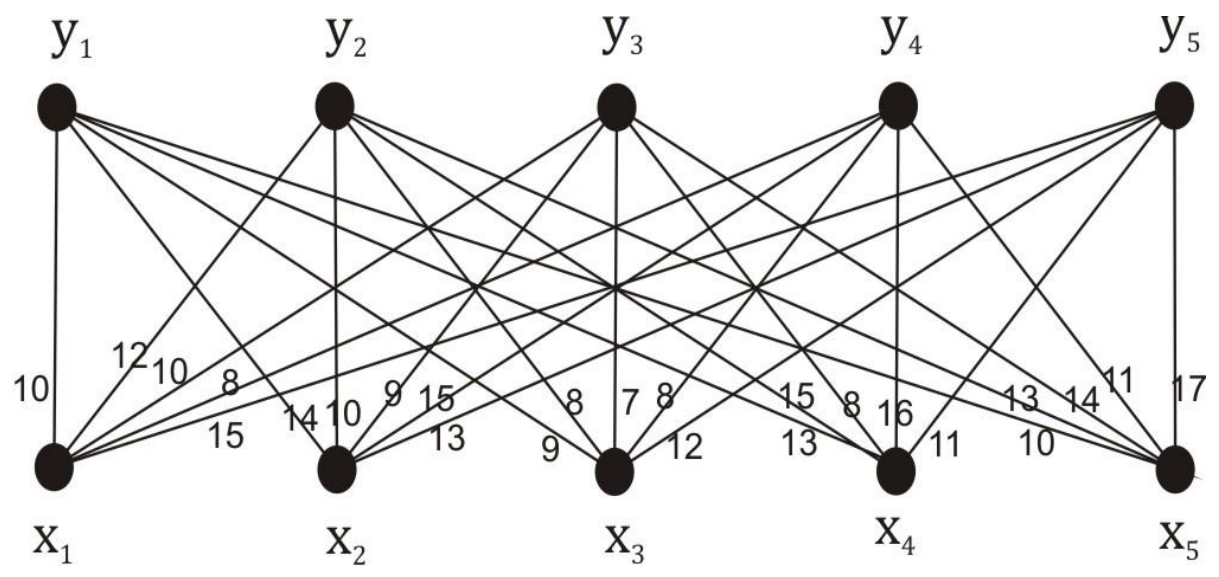

Gambar 1 Graf dari ilustrasi penempatan karyawan.

Untuk mencari solusi optimal dari penempatan karyawan sama halnya dengan mencari matching sempurna dengan bobot maksimum pada graf bipartit pada gambar 1. Karena graf $G$ merupakan graf bipartit lengkap yang memiliki partisi $\{X, Y\}$ dengan $|X|=|Y|$ dan $|S| \leq\left|N_{\mathrm{G}}(S)\right|(S \subseteq X$ atau $Y)$, berdasarkan teorema marriage yang telah dijelaskan pada bab sebelumnya, maka pada graf bipartit ini terdapat matching sempurna. Dalam hal ini karena $|X|=|Y|=5$, maka dapat ditentukan kemungkinan matching sempurnanya sebanyak $5 !=120$.

Pada dasarnya pencarian matching sempurna dengan bobot maksimal dapat dilakukan dengan mendaftar semua matching sempurna yang berbeda, dan menghitung jumlah bobot dari tiap matching sempurna yang diperoleh. Dalam masalah ini, karena kemungkinan matching sebanyak 120, pencarian 
solusi dengan mendaftar semua matching sempurna yang mungkin pada graf bipartit tersebut sangat tidak efisien untuk digunakan. Oleh karena itu, untuk memudahkan pencarian solusi dari penempatan karyawan tersebut, akan digunakan sebuah metode optimasi yaitu metode Hungarian. Sebelum menguraikan langkah-langkah dalam metode Hungarian, akan didefinisikan terlebih dahulu feasible labelling dan equality subgraph.

\section{Feasible Labelling}

Misalkan terdapat suatu graf bipartit lengkap $G$ dengan bobot $w$ yang dinotasikan dengan $(G, w)$. Feasible labelling pada graf $G$ didefinisikan sebagai fungsi nilai real $\ell$ pada $X \cup Y$ sedemikian sehingga untuk setiap $x \in X$ dan $y \in Y$ berlaku:

$$
\ell(x)+\ell(y) \geq w(x, y)
$$

Salah satu cara untuk menemukan feasible labelling adalah dengan mendefinisikan semua $\ell(y)=$ 0 untuk $y \in Y$ dan untuk setiap $x \in X$, ambil bobot maksimum pada sisi yang bersisian dengan $x$.

$$
\begin{array}{lll}
\forall y \in \mathrm{Y}, \ell(y)=0 & \text { untuk } y \in \mathrm{Y} & \forall x \in \mathrm{X}, \ell(x) \\
\max _{\mathrm{y} \in \mathrm{Y}\{\mathrm{w}(x, y)\}} & \text { untuk } x \in \mathrm{X} &
\end{array}
$$

Contoh 2:

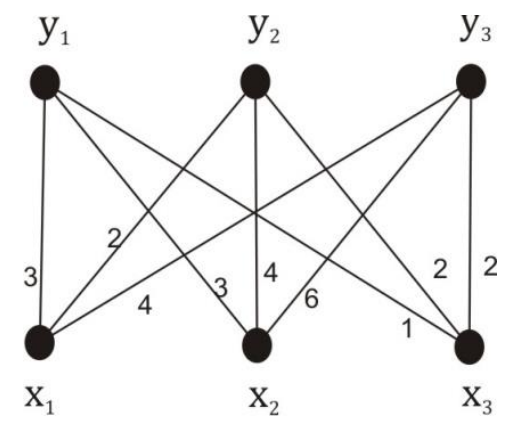

Gambar 2 Graf bipartit lengkap berbobot.

Akan ditentukan feasible labelling dari graf bipartit berbobot pada gambar 2. Diperoleh matriks ketetanggaan yang bersesuaian dengan gambar 2 adalah:

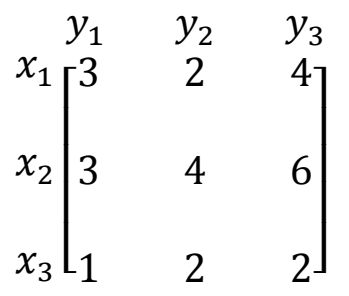

Dari penjelasannya sebelumnya salah satu cara untuk menemukan feasible labelling adalah dengan mendefinisikan semua $\ell(y)=0$ untuk $y \in Y$ dan untuk setiap $\in X$, ambil bobot maksimum pada sisi yang bersisian dengan $x$.

$$
\begin{array}{ll}
\forall y \in Y, \ell(y)=0 & \text { untuk } y \in Y \\
\forall x \in X, \ell(\mathrm{x})=\max _{\mathrm{y} \in \mathrm{Y}}\{\mathrm{w}(\mathrm{x}, \mathrm{y})\} & \text { untuk } x \in X
\end{array}
$$

Dalam hal ini untuk mendefinisikan $\ell(y)=0$ untuk $y \in Y$, dapat dilakukan dengan menuliskan angka 0 dibawah matriks untuk masing-masing $y$ seperti pada matriks berikut ini:

$$
\begin{array}{lll}
y_{1} & y_{2} & y_{3}
\end{array}
$$




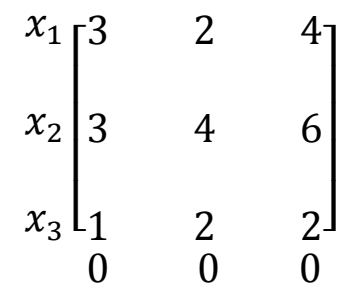

Selanjutnya untuk mendefinisikan $\forall \mathrm{x} \in X, \ell(\mathrm{x})=\max _{\mathrm{y} \in \mathrm{Y}}\{\mathrm{w}(\mathrm{x}, \mathrm{y})\}$ dapat dilakukan dengan cara mencari nilai maksimum untuk setiap baris yang sama kemudian menuliskannya pada samping kanan matriks, seperti pada matriks berikut ini:

(Catatan: angka yang dicetak tebal menunjukkan nilai maksimum di setiap baris)

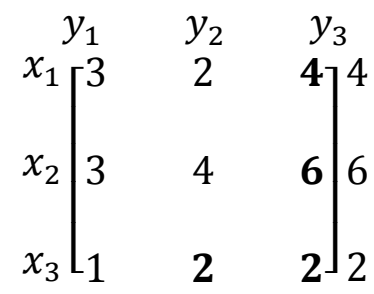

maka diperoleh feasible labelling yang diilustrasikan pada matriks berikut ini:

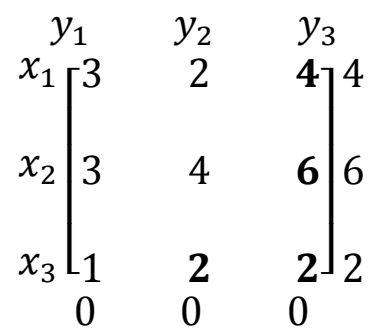

Pelabelan simpul $\ell$ yang bersesuaian dengan gambar 2 adalah sebagai berikut:

$\forall y \in Y, \ell\left(y_{1}, y_{2}, y_{3}\right)=(0,0,0)$

$\forall x \in X, \ell\left(x_{1}, x_{2}, x_{3}\right)=(4,6,2)$

\section{Equality Subgraph}

Misalkan terdapat suatu feasible labelling pada graf $G$, maka equality subgraph yang berkorespondensi dengan feasible labelling $\ell$ didefinisikan sebagai spanning subgraph dari $G$ dengan himpunan sisi $\mathrm{E}_{\ell}$, dengan $\mathrm{E}_{\ell}=\{x y: \ell(x)+\ell(y)=\mathrm{w}(x, y)\}$, dan dinotasikan dengan $\mathrm{G}_{\ell}$.

Contoh 3:

Akan ditentukan equality subgraph dari graf bipartit lengkap berbobot pada gambar 2 .

Penyelesaian:

Untuk mencari equality subgraph dapat dilakukan dengan menghimpun semua sisi $\mathrm{E}_{\ell}$ yang bersesuaian dengan feasible labelling dari graf bipartit berbobot pada gambar 2, sedemikian sehingga $\mathrm{E}_{\ell}=\{x y$ : $\ell(x)+\ell(y)=\mathrm{w}(x, y)\}$, dengan kata lain sisi $E_{\ell}$ adalah sisi yang mempunyai bobot yang sama dengan feasible labelling yaitu $\left(x_{1} y_{3}, x_{2} y_{3}, x_{3} y_{2}, x_{3} y_{3}\right)$.

Selanjutnya diperoleh equality subgraph $G_{\ell}$ seperti pada gambar 3 berikut ini: 
Gambar 3 Contoh equality subgraph $G_{\ell}$.

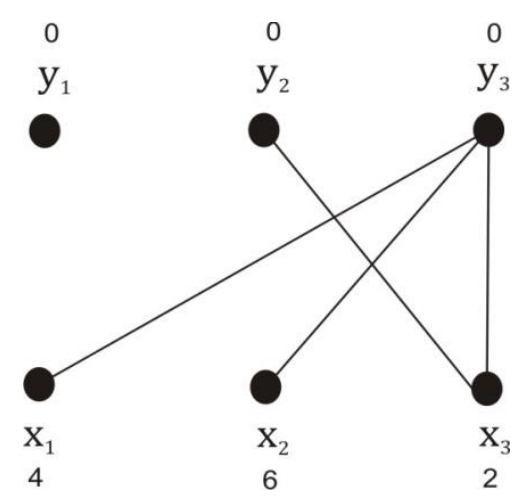

Teorema 3.1 Jika $\ell$ adalah feasible labelling dan $M$ adalah matching sempurna pada $\mathrm{E}_{\ell}$, maka $M$ merupakan matching dengan bobot maksimum. (Junming $\mathrm{Xu}, 2003$ )

\section{Bukti:}

Misalkan $M^{*}$ adalah matching sempurna dari suatu equality subgraph $G_{\ell}$, maka $M^{*}$ juga merupakan matching sempurna dari $G$ karena $G_{\ell}$ adalah spanning subgraph dari $G$.

Masing-masing $e \in M^{*}$ merupakan anggota dari $G_{\ell}$ dan simpul-simpul akhir dari sisi pada $M^{*}$ menyatukan setiap simpul tepat satu kali, maka diperoleh:

$$
w\left(M^{*}\right)=\sum_{e \in M} w(e)=\sum_{x \in V} \ell(\mathrm{x})
$$

Jika $M$ adalah sebarang matching sempurna lain dari $G$, maka:

$$
w(M)=\sum_{e \in M} w(e) \leq \sum_{x \in V} \ell(x)
$$

Dari (1) dan (2) diperoleh $w\left(M^{*}\right) \geq w(M)$, maka $M^{*}$ adalah matching optimal dari $G$.

\section{Metode Hungarian}

Untuk menyelesaikan masalah penempatan karyawan, metode Hungarian dapat direpresentasikan dengan graf bipartit lengkap berbobot. Adapun langkah-langkah dalam metode Hungarian adalah sebagai beikut:

1. Melakukan inisialisasi pelabelan simpul $\ell$ dan bentuk Equality subgraph $G_{\ell}$ :

a. $\forall y \in Y, \ell(y)=0$

b. $\forall x \in X, \ell(x)=\max _{\mathrm{y} \in \mathrm{Y}}\{w(x, y)\}$.

2. Pilih sebarang matching $M$ di $G_{\ell}$.

3. Jika mendapatkan $M$ sempurna berdasarkan teorema 3.1, maka proses berhenti. Jika tidak pilih sebarang simpul $u \in X$ yang unsaturated di $M$, dan didefinisikan $S=\{u\}, T=\varnothing(S \subseteq X$ dan $T \subseteq$ $Y)$.

4. Jika $N_{G_{\ell}}(S)=T$, maka perbaharui label $\ell$, jika tidak lanjut ke langkah 5. Hitung $\alpha_{\ell}$ dan tambahkan sisi $\alpha_{\ell}$ pada graf $G_{\ell}$.

$$
\alpha_{\ell}=\min _{x \in S, y \notin T}\{\ell(x)+\ell(y)-\mathrm{w}(x, y)\}
$$

Maka berlaku pelabelan simpul yang baru $\ell^{\prime}$ :

$$
\ell^{\prime}(v)=\left\{\begin{array}{l}
\ell(v)-\alpha_{\ell} \text { untuk } v \in \mathrm{S} \\
\ell(v)+\alpha_{\ell} \text { untuk } v \in \mathrm{T} \\
\ell(v) \text { yang lainnya }
\end{array}\right.
$$

5. $N_{G_{\ell}}(S) \neq T$, maka pilih $y \in N_{G_{\ell}}(S)-T$ 
- Jika $y$ matched misalkan sampai $z$, dengan $z \in X$ dan $y z \in M$, maka bentuk lintasan $M$-alternating dengan menambahkan $S=S \cup\{z\}$ dan $T=T \cup\{y\}$, kemudian kembali ke langkah 4 .

- Sebaliknya apabila $y$ bebas (unmatched), maka akan terdapat $P$ yang merupakan lintasan $M$ augmenting $u-y$, kemudian ganti $M$ dengan $M^{\prime}=M \Delta P$, yaitu mengganti sisi matching menjadi tidak matching dan sebaliknya pada lintasan $M$-Augmenting dan kembali ke langkah 3.

\section{Contoh 4:}

Akan dicari solusi dari contoh 1 dengan menggunakan metode Hungarian.

Penyelesaian:

1. Melakukan pelabelan simpul $\ell$ dan dibentuk equality subgraph $G_{\ell}$. Diperoleh feasible labelling yang diilustrasikan pada matriks berikut ini:

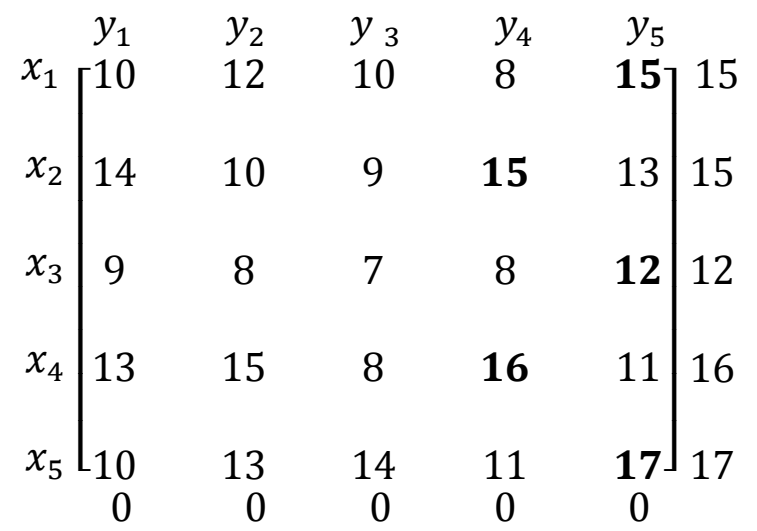

Sehingga diperoleh pelabelan simpul $\ell$ :

a. $\forall y \in Y, \ell\left(y_{1}, y_{2}, y_{3}, y_{4}, y_{5}\right)=(0,0,0,0,0,0)$

b. $\forall x \in X, \ell\left(x_{1}, x_{2}, x_{3}, x_{4}, x_{5}\right)=(15,15,12,16,17)$

Berdasarkan pelabelan simpul $\ell$, diperoleh equality subgraph $G_{\ell}$ seperti pada gambar 4 berikut ini:

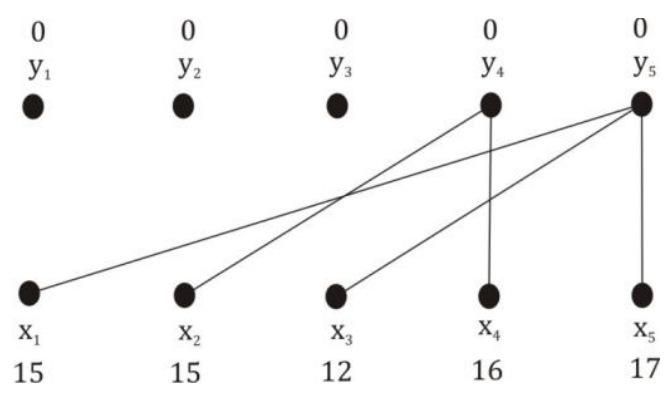

Gambar 4 Equality subgraph $\boldsymbol{G}_{\boldsymbol{\ell}}$.

2. Pilih sebarang matching $M$ (ditandai dengan sisi yang dicetak tebal) di equality subgraph $G_{\ell}$ pada gambar 4, misal dipilih $M=\left(x_{4}, y_{4}\right),\left(x_{5}, y_{5}\right)$

Gambar 5 Matching $\boldsymbol{M}$.

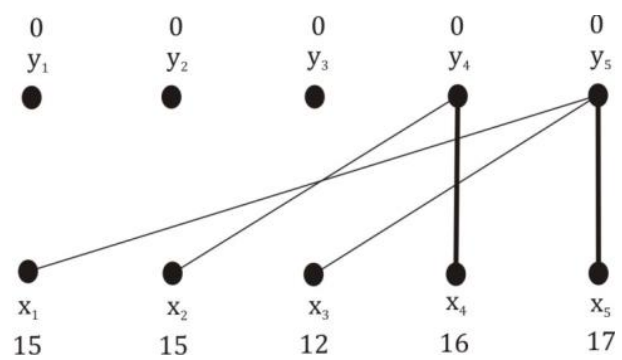


3. Matching $M$ pada gambar 5 bukan merupakan matching sempurna, karena $G_{\ell}$ belum memuat semua simpul dan masih terdapat simpul pada $X$ yang unsaturated di $M$, maka pilih sebarang $u \in$ $X$ yang unsaturated di $M$. Didapatkan simpul $x_{1}, x_{2}, x_{3} \in X$, sehingga didefinisikan $S=\left\{x_{1}, x_{2}, x_{3}\right\}$ dan $\mathrm{T}=\varnothing$.

4. Berdasarkan langkah 3, diperoleh $S=\left\{x_{1}, x_{2}, x_{3}\right\}, \mathrm{T}=\varnothing$ dan simpul yang bertetangga dengan simpul di $S$ adalah $y_{4}$ dan $y_{5}$, maka $N_{G_{\ell}}(S)=\left\{y_{4}, y_{5}\right\}$. Karena $N_{G_{\ell}}(S) \neq T$, lanjutkan ke langkah 5 menggunakan algoritma hungarian, yaitu pilih $y \in N_{G_{\ell}}(S)-T$. Misalkan $y$ matched sampai $z$, dengan $z \in X$ dan $y z \in M$, maka bentuk lintasan $M$-alternating dengan menambahkan $S=S \cup$ $\{z\}$ dan $T=T \cup\{y\}$. Dalam hal ini diperoleh $y_{4}, y_{5} \in N_{G_{\ell}}(S)-T$, karena $y_{4}, y_{5}$ Matched di Matching $M$ dengan $x_{4}, x_{5} \in X$ dan $x_{4} y_{4}, x_{5} y_{5} \in M$, maka akan dibentuk lintasan $M$-alternating dengan menambahkan $S=\left\{x_{1}, x_{2}, x_{3}\right\} \cup\left\{x_{4}, x_{5}\right\}$ atau $S=\left\{x_{1}, x_{2}, x_{3}, x_{4}, x_{5}\right\}$ dan $T=\emptyset \cup\left\{y_{4}, y_{5}\right\}$ atau $T=\left\{y_{4}, y_{5}\right\}$.

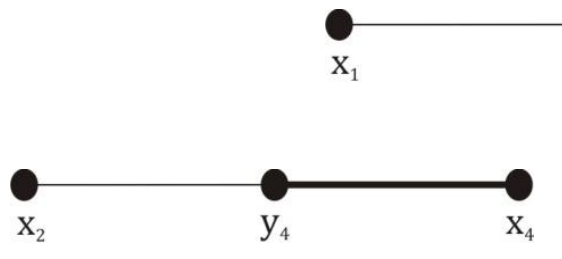

(b) (a)

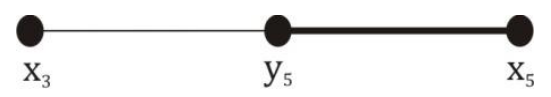

(c)

Gambar 6 (a) Lintasan $\boldsymbol{M}$-alternating berawal dari simpul $\boldsymbol{x}_{\mathbf{1}}$, (b) Lintasan $\boldsymbol{M}$-alternating berawal dari simpul $\boldsymbol{x}_{\mathbf{2}}$, (c) Lintasan $\boldsymbol{M}$-alternating berawal dari simpul $\boldsymbol{x}_{\mathbf{3}}$

5. Berdasarkan langkah 4 diperoleh $S=\left\{x_{1}, x_{2}, x_{3}, x_{4}, x_{5}\right\}, T=\left\{y_{4}, y_{5}\right\}$ dan simpul yang bertetangga dengan simpul-simpul di $S$ adalah $y_{4}$ dan $y_{5}$, maka $N_{G_{\ell}}(S)=\left\{y_{4}, y_{5}\right\}$. Dalam hal ini $N_{G_{\ell}}(S)=T$ maka lanjutkan ke langkah 4 dalam algoritma.

Hitung $\alpha_{\ell}$ 


$$
\alpha_{\ell}=\min _{x \in S, y \notin T}\left\{\begin{array}{l}
15+0-10=5,\left(x_{1}, y_{1}\right) \\
15+0-12=3,\left(x_{1}, y_{2}\right) \\
15+0-10=5,\left(x_{1}, y_{3}\right) \\
15+\mathbf{0}-\mathbf{1 4}=\mathbf{1},\left(x_{2}, y_{1}\right) \\
15+0-10=5,\left(x_{2}, y_{2}\right) \\
15+0-9=6,\left(x_{2}, y_{3}\right) \\
12+0-9=3,\left(x_{3}, y_{1}\right) \\
12+0-7=5,\left(x_{3}, y_{3}\right) \\
16+0-13=3,\left(x_{4}, y_{1}\right) \\
16+\mathbf{0}-\mathbf{1 5}=\mathbf{1},\left(x_{4}, y_{2}\right) \\
16+0-8=8,\left(x_{4}, y_{3}\right) \\
17+0-10=7,\left(x_{5}, y_{1}\right) \\
17+0-13=4,\left(x_{5}, y_{2}\right) \\
17+0-14=3,\left(x_{5}, y_{3}\right)
\end{array}\right.
$$

Diperoleh $\alpha_{\ell}=1$ yaitu pada $\left(x_{2}, y_{1}\right),\left(\mathrm{x}_{4}, \mathrm{y}_{2}\right)$ dan tambahkan sisi-sisi tersebut pada graf $G_{\ell}$. Kurangi elemen-elemen pada label $S=\left\{x_{1}, x_{2}, x_{3}, x_{4}, x_{5}\right\}$ dengan 1, dan tambahkan elemen-elemen label dari $T=\left\{y_{4}, y_{5}\right\}$ dengan 1 .

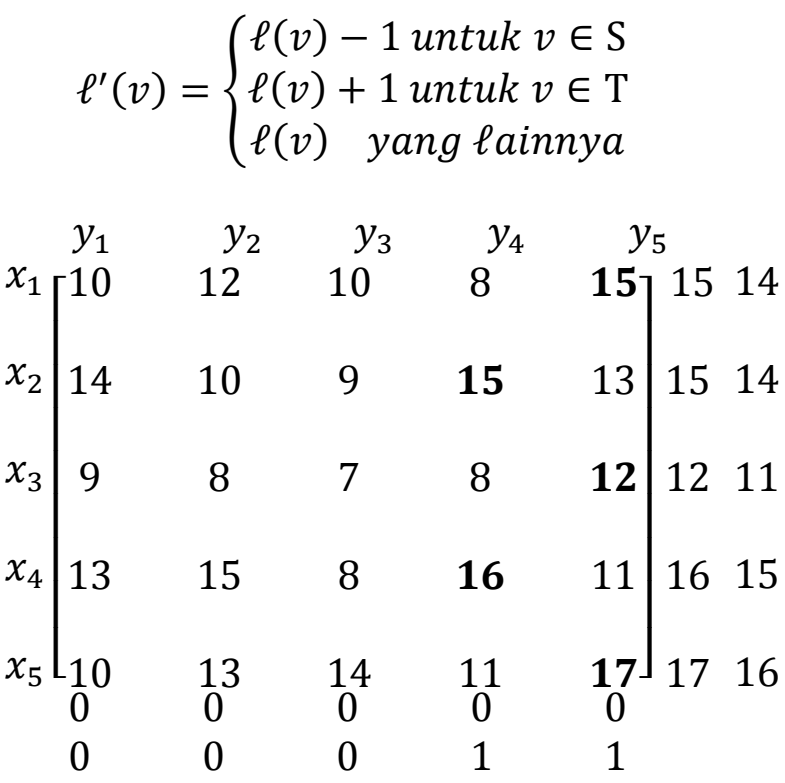

Sehingga diperoleh pelabelan simpul $\ell^{\prime}$ : 
a. $\forall y \in Y, \ell\left(y_{1}, y_{2}, y_{3}, y_{4}, y_{5}\right)=(0,0,0,0,1,1)$

b. $\forall x \in \mathrm{X}, \ell^{\prime}\left(x_{1}, x_{2}, x_{3}, x_{4}, x_{5}\right)=(14,14,11,15,16)$

Berdasarkan gambar 5 dan pelabelan simpul baru $\ell^{\prime}$ diperoleh equality subgraph $G_{\ell}{ }^{\prime}$ dan sebarang matching $M$ yang ditandai dengan sisi yang dicetak tebal seperti pada gambar 7 berikut:

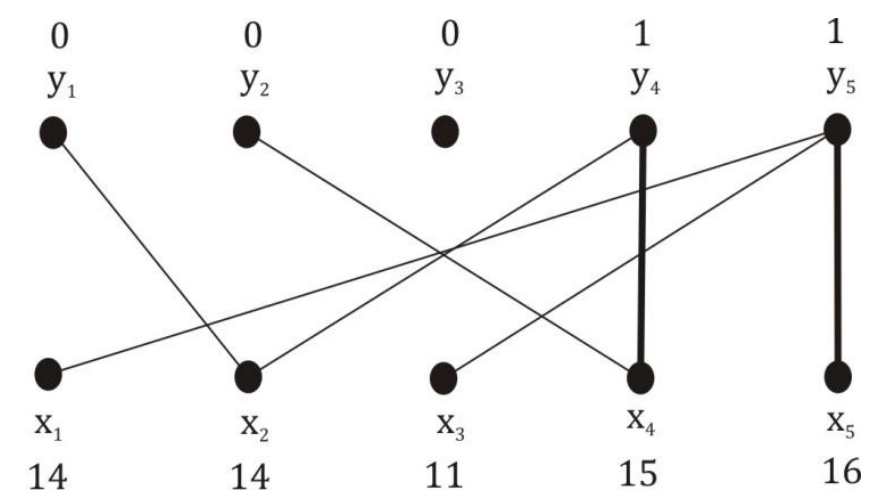

Gambar 7 Equality subgraph $\boldsymbol{G}_{\boldsymbol{\ell}}{ }^{\prime}$ dan matching $\boldsymbol{M}$.

6. Berdasarkan langkah 5 dan gambar 7 , diperoleh $S=\left\{x_{1}, x_{2}, x_{3}, x_{4}, x_{5}\right\}, T=\left\{y_{4}, y_{5}\right\}$ dan simpulsimpul yang bertetangga dengan simpul-simpul di $S$ adalah $y_{1}, y_{2}, y_{4}$ dan $y_{5}$ sehingga $N_{G_{\ell^{\prime}}}(S)=\left\{y_{1}, y_{2}, y_{4}, y_{5}\right\}$. Karena $N_{G_{\ell^{\prime}}}(S) \neq T$, maka lanjutkan ke langkah 5 menggunakan algoritma hungarian, yaitu pilih

$$
y \in N_{G_{\ell^{\prime}}}(S) \mathrm{T}
$$

7. Dalam hal ini diperoleh $y_{1}, y_{2} \in N_{G_{\ell^{\prime}}}(S)-T$. Karena $y_{1}, y_{2}$ bebas (unmatched), sehingga menurut langkah 5 dalam algoritma Hungarian akan terdapat $P$ yang merupakan lintasan $M$-augmenting $u-y$, yaitu $P_{1}=\left\{\left(x_{2}, y_{4}\right),\left(x_{4}, y_{4}\right),\left(x_{4}, y_{2}\right)\right\}$ dengan dua titik akhir bebas,

maka ganti $M$ dengan $M^{\prime}=M \Delta P_{1}$ yaitu mengganti sisi matching menjadi tidak matching dan sebaliknya pada lintasan $M$-augmenting dan kembali ke langkah 3.

$M^{\prime}=M \Delta P_{1}$

$M^{\prime}=\left\{\left(x_{4}, y_{4}\right),\left(x_{5}, y_{5}\right)\right\} \Delta\left\{\left(x_{2}, y_{4}\right),\left(x_{4}, y_{4}\right),\left(x_{4}, y_{2}\right)\right\}$

$M^{\prime}=\left\{\left(x_{2}, y_{4}\right),\left(x_{4}, y_{2}\right),\left(x_{5}, y_{5}\right)\right\}$

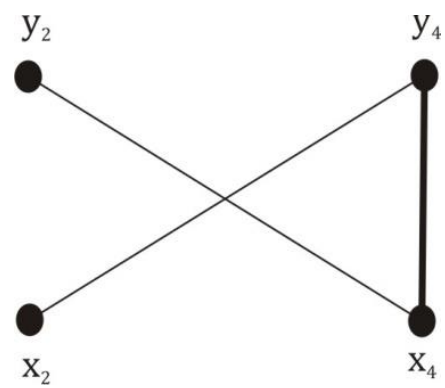

Gambar 8 Lintasan $\boldsymbol{M}$-Augmenting $\boldsymbol{P}_{\mathbf{1}}$.

Berdasarkan gambar 8 didapatkan matching baru $M^{\prime}=\left(x_{2}, y_{4}\right),\left(x_{4}, y_{2}\right),\left(x_{5}, y_{5}\right)$. Matching $M$ tersebut bukan merupakan matching sempurna, karena masih terdapat simpul pada $X$ yang unsaturated di $M^{\prime}$, maka pilih sebarang $u \in X$ yang unsaturated di $M$. Didapatkan simpul $x_{1}, x_{3} \in$ $X$ sehingga didefinisikan $S=\left\{x_{1}, x_{3}\right\}$ dan $T=\emptyset$. 


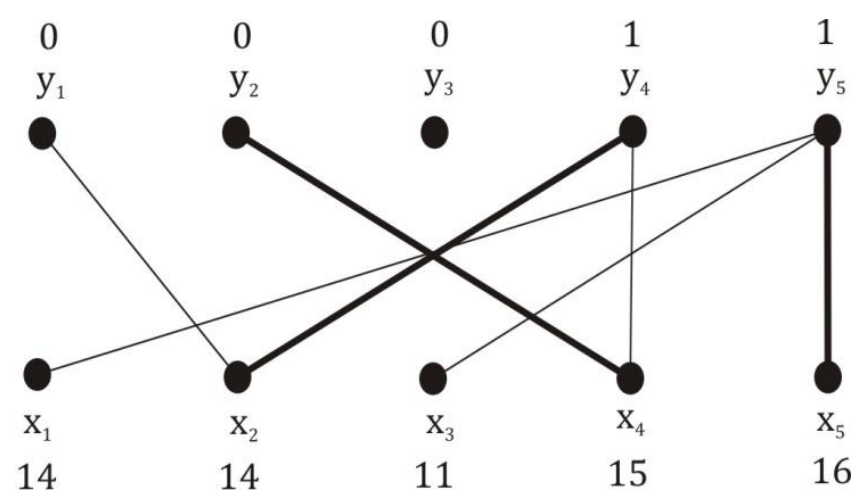

Gambar 9 Equality Subgraph $\boldsymbol{G}_{\boldsymbol{\ell}}{ }^{\prime}$ dan Matching $\boldsymbol{M}^{\prime}$

8. Berdasarkan langkah 7 dan gambar 9 diperoleh $S=\left\{x_{1}, x_{3}\right\}, T=\varnothing$ dan simpul yang bertetangga dengan simpul-simpul di $S$ adalah $y_{5}$ maka $N_{G_{\ell^{\prime}}}(S)=\left\{y_{5}\right\}$. Karena $N_{G_{\ell^{\prime}}}(S) \neq T$, maka lanjutkan ke langkah 5 menggunakan algoritma hungarian, yaitu pilih $y \in N_{G_{\ell^{\prime}}}(S)-T$. Misalkan $y$ matched sampai $z$, dengan $z \in X$ dan $y z \in M$ maka bentuk lintasan $M$-alternating dengan menambahkan $S=$ $S \cup\{z\}$ dan $T=T \cup\{y\}$. Dalam hal ini diperoleh $y_{5} \in N_{G_{\ell^{\prime}}}(S) \mathrm{T}, y_{5}$ matched di matching $M$ dengan $x_{5} \in X$ dan $x_{5} y_{5} \in M$, maka akan dibentuk lintasan $M$-alternating dengan menambahkan $S=$ $\left\{x_{1}, x_{3}\right\} \cup\left\{x_{5}\right\}$ atau $S=\left\{x_{1}, x_{3}, x_{5}\right\}$ dan $T=\emptyset \cup\left\{y_{5}\right\}$ atau $T=\left\{y_{5}\right\}$.



(b)

Gambar 10 (a) Lintasan $\boldsymbol{M}$-alternating berawal dari simpul $\boldsymbol{x}_{\mathbf{1}}$, (b) Lintasan $\boldsymbol{M}$-alternating berawal dari simpul $\boldsymbol{x}_{\mathbf{3}}$,

9. Berdasarkan langkah 8 diperoleh $S=\left\{x_{1}, x_{3}, x_{5}\right\}, T=\left\{y_{5}\right\}$ dan simpul yang bertetangga dengan simpul-simpul di $S$ adalah $y_{5}$, maka $N_{G_{\ell^{\prime}}}(S)=\left\{y_{5}\right\}$, dalam hal ini $N_{G_{\ell^{\prime}}}(S)=T$ maka lanjutkan ke langkah 4 dalam algoritma.

Hitung $\alpha_{\ell}$ 


$$
\alpha_{\ell}=\min _{x \in S, y \notin T}\left\{\begin{array}{c}
14+0-10=4,\left(x_{1}, y_{1}\right) \\
\mathbf{1 4} \mathbf{0}-\mathbf{1 2}=\mathbf{2},\left(\boldsymbol{x}_{\mathbf{1}}, \boldsymbol{y}_{2}\right) \\
14+0-10=4,\left(x_{1}, y_{3}\right) \\
14+1-8=7,\left(x_{1}, y_{4}\right) \\
\mathbf{1 1}+\mathbf{0}-\mathbf{9}=\mathbf{2},\left(\boldsymbol{x}_{3}, \boldsymbol{y}_{\mathbf{1}}\right) \\
11+0-8=3,\left(x_{3}, y_{2}\right) \\
11+0-7=4,\left(x_{3}, y_{3}\right) \\
11+1-8=4,\left(x_{3}, y_{4}\right) \\
16+0-10=6,\left(x_{5}, y_{1}\right) \\
16+0-13=3,\left(x_{5}, y_{2}\right) \\
\mathbf{1 6}+\mathbf{0}-\mathbf{1 4}=\mathbf{2},\left(\boldsymbol{x}_{\mathbf{5}}, \boldsymbol{y}_{3}\right) \\
16+1-11=6,\left(x_{5}, y_{4}\right) \\
=2
\end{array}\right.
$$

Didapatkan $\alpha_{\ell}=2$ yaitu pada $\left(x_{1}, y_{2}\right),\left(x_{3}, y_{1}\right)$ dan $\left(x_{5}, y_{3}\right)$. Tambahkan sisi-sisi tersebut pada graf $G_{\ell}^{\prime}$.

Kurangi elemen-elemen pada label $S=\left\{x_{1}, x_{3}, x_{5}\right\}$ dengan 2 dan tambahkan elemen label dari $T=\left\{y_{5}\right\}$ dengan 2 .

$\ell^{\prime \prime}(v)=\left\{\begin{array}{l}\ell^{\prime}(v)-2 \text { untuk } v \in \mathrm{S} \\ \ell^{\prime}(v)+2 \text { untuk } v \in \mathrm{T} \\ \ell^{\prime}(v) \text { yang lainnya }\end{array}\right.$

\begin{tabular}{|c|c|c|c|c|c|c|c|}
\hline & $y_{1}$ & $y_{2}$ & $y_{3}$ & $y$ & \multicolumn{3}{|c|}{$y_{5}$} \\
\hline$x_{1}$ & 10 & 12 & 10 & 8 & 15 & 15 & 141 \\
\hline \begin{tabular}{l|l}
$x_{2}$ & 1
\end{tabular} & 14 & 10 & 9 & 15 & 13 & 15 & 141 \\
\hline$x_{3}$ & 9 & 8 & 7 & 8 & 12 & 12 & 11 \\
\hline \begin{tabular}{l|l}
$x_{4}$ & 1
\end{tabular} & 13 & 15 & 8 & 16 & 11 & 16 & 151 \\
\hline$x_{5} L_{1}$ & 10 & 13 & 14 & 11 & 17 & & 16 \\
\hline & 0 & 0 & 0 & 1 & 1 & & \\
\hline & 0 & 0 & 0 & 1 & 3 & & \\
\hline
\end{tabular}

Sehingga diperoleh pelabelan simpul $\ell^{\prime \prime}$ :

a. $\forall y \in Y, \ell^{\prime \prime}\left(y_{1}, y_{2}, y_{3}, y_{4}, y_{5}\right)=(0,0,0,0,1,3)$

b. $\forall x \in \mathrm{X}, \ell^{\prime \prime}\left(x_{1}, x_{2}, x_{3}, x_{4}, x_{5}\right)=(12,14,9,15,14)$ 
Berdasarkan gambar 9 dan pelabelan simpul baru $\ell^{\prime \prime}$ diperoleh equality subgraph $G_{\ell}{ }^{\prime \prime}$ dan matching $M$ yang ditandai dengan rusuk yang dicetak tebal seperti pada gambar 11 berikut:

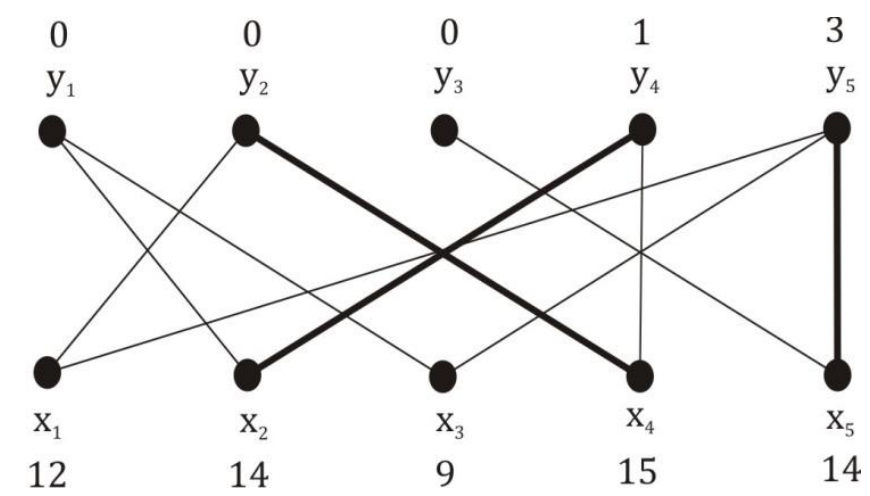

Gambar 11 Equality subgraph $\boldsymbol{G}_{\boldsymbol{\ell}}{ }^{\prime \prime}$ dan matching $\boldsymbol{M}^{\prime}$.

10. Berdasarkan langkah 9, dan gambar 11 diperoleh $S=\left\{x_{1}, x_{3}, x_{5}\right\}, T=\left\{y_{5}\right\}$ dan simpul-simpul yang bertetangga dengan simpul-simpul di $S$ adalah $y_{1}, y_{2}, y_{3}$ dan $y_{5}$ maka $N_{G_{\ell^{\prime \prime}}}(S)=\left\{y_{1}, y_{2}, y_{3}, y_{5}\right\}$. Karena $N_{G_{\ell^{\prime \prime}}}(S) \neq T$ maka lanjutkan ke langkah 5 menggunakan algoritma hungarian, yaitu pilih y $\in N_{G_{\ell} \prime}(S) \mathrm{T}$.

11. Berdasarkan langkah 10 diperoleh $y_{1}, y_{2}, y_{3} \in N_{G_{\ell^{\prime \prime}}}(S)-T$. Dalam hal ini $y_{2}$ matched di $M$ dan $y_{2}, y_{3}$ bebas (unmatched) sehingga menurut langkah 5 dalam algoritma Hungarian akan terdapat $P$ yang merupakan lintasan $M$-augmenting $u-y$. Berdasarkan gambar 11 diperoleh 2 lintasan $M$-augmenting yaitu:

$P_{2}=\left\{\left(x_{1}, y_{2}\right),\left(x_{2}, y_{1}\right)\left(x_{2}, y_{4}\right)\left(x_{4}, y_{2}\right)\left(x_{4}, y_{4}\right)\right\} P_{3}=\left\{\left(x_{3}, y_{5}\right),\left(x_{5}, y_{3}\right),\left(x_{5}, y_{5}\right)\right\}$

maka ganti $M^{\prime}$ dengan $M^{\prime \prime}=M^{\prime} \Delta P_{2} \Delta P_{3}$ yaitu mengganti sisi matching menjadi tidak matching dan sebaliknya pada lintasan $M$-augmenting dan kembali ke langkah 3 .

$M^{\prime \prime}=M^{\prime} \Delta P_{2} \Delta P_{3}$

$M^{\prime \prime}=\left\{\left(x_{2}, y_{4}\right),\left(x_{4}, y_{2}\right),\left(x_{5}, y_{5}\right)\right\} \Delta$

$\left\{\left(x_{1}, y_{2}\right),\left(x_{2}, y_{1}\right)\left(x_{2}, y_{4}\right)\left(x_{4}, y_{2}\right)\left(x_{4}, y_{4}\right)\right\} \Delta\left\{\left(x_{3}, y_{5}\right),\left(x_{5}, y_{3}\right),\left(x_{5}, y_{5}\right)\right\}$

$M^{\prime \prime}=\left\{\left(x_{1}, y_{2}\right),\left(x_{2}, y_{1}\right),\left(x_{4}, y_{4}\right),\left(x_{3}, y_{5}\right),\left(x_{5}, y_{3}\right)\right\}$

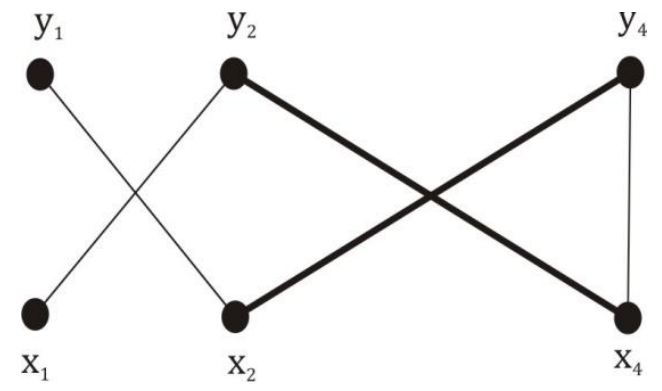

Gambar 12 Lintasan $\boldsymbol{M}$-augmenting $\boldsymbol{P}_{\mathbf{2}}$.

Gambar 13 Lintasan $\boldsymbol{M}$-augmenting $\boldsymbol{P}_{\mathbf{3}}$.




Berdasarkan Gambar 11 didapatkan matching baru $M^{\prime \prime}=\left\{\left(x_{1}, y_{2}\right),\left(x_{2}, y_{1}\right),\left(x_{4}, y_{4}\right),\left(x_{3}, y_{5}\right),\left(x_{5}, y_{3}\right)\right\}$.

Matching $M^{\prime \prime}$ tersebut dapat dikatakan sempurna karena sudah memuat semua simpul dalam equality subgraph $G_{\ell}{ }^{\prime \prime}$, sehingga matching tersebut sudah optimal sehingga algoritma berhenti.



Gambar 14 Equality subgraph $\boldsymbol{G}_{\boldsymbol{\ell}}{ }^{\prime \prime}$ dan Matching $\boldsymbol{M}^{\prime \prime}$.

12. Dari langkah-langkah di atas diperoleh matching sempurna

$M=\left\{\left(x_{1}, y_{2}\right),\left(x_{2}, y_{1}\right),\left(x_{4}, y_{4}\right),\left(x_{3}, y_{5}\right),\left(x_{5}, y_{3}\right)\right\}$,

maka diperoleh nilai solusi optimal dengan menjumlahkan nilai-nilai feasible labeling pada equality subgraph $G_{\ell}$, yaitu:

$12+14+9+15+14+3+1+0+0+0=68$.

Perhatikan bahwa nilai ini akan sama dengan total bobot dari matching sempurna $M$ yaitu:

$w\left(x_{1}, y_{2}\right)+\mathrm{w}\left(x_{2}, y_{1}\right)+w\left(x_{4}, y_{4}\right)+\mathrm{w}\left(x_{3}, y_{5}\right)+\mathrm{w}\left(x_{5}, y_{3}\right)$

$=12+14+16+12+14=68$

13. Jadi penempatan karyawan pada masing-masing pekerjaan adalah sebagai berikut:
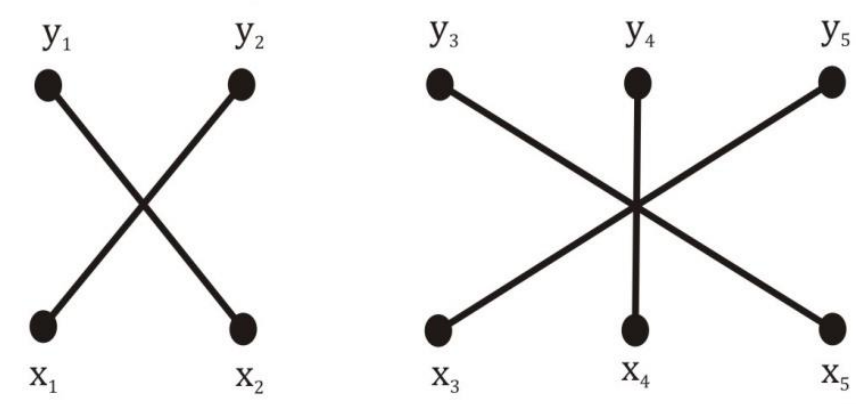

Gambar 15 Matching sebagai solusi masalah penempatan karyawan.

Berdasarkan hasil matching pada gambar 15 untuk mendapatkan hasil yang optimal, maka penempatan karyawan yang sebaiknya dilakukan oleh perusahaan adalah sebagai berikut:

- Karyawan Afif $\left(x_{1}\right)$ ditugaskan mengerjakan pekerjaan II $\left(y_{2}\right)$, dengan produk yang dihasilkan sebanyak 12.

- Karyawan Bady $\left(x_{2}\right)$ ditugaskan mengerjakan pekerjaan I $\left(y_{1}\right)$, dengan produk yang dihasilkan sebanyak 14.

- Karyawan Dzaki $\left(x_{3}\right)$ ditugaskan mengerjakan pekerjaan $\vee\left(y_{5}\right)$, dengan produk yang dihasilkan sebanyak 12.

- Karyawan Faras $\left(x_{4}\right)$ ditugaskan mengerjakan pekerjaan IV $\left(y_{4}\right)$, dengan produk yang dihasilkan sebanyak 16.

- Karyawan Ghazy $\left(x_{5}\right)$ ditugaskan mengerjakan pekerjaan III $\left(y_{3}\right)$, dengan produk yang dihasilkan sebanyak 14. 
Dengan demikian dapat disimpulkan bahwa dengan metode Hungarian, masalah penempatan karyawan pada perusahaan distro dapat diselesaikan dengan jumlah produk maksimum yang dapat dihasilkan adalah sebanyak 68 tiap bulannya.

\section{Kesimpulan}

Dari penjelasan yang telah diuraikan sebelumnya, maka dapat disimpulkan beberapa hal sebagai berikut:

1. Langkah-langkah metode Hungarian pada graf bipartit lengkap berbobot dengan $|X|=|Y|$, akan menghasilkan matching sempurna dengan bobot yang optimal, dimana semua himpunan simpul di $X$ dan $Y$ saturated oleh matching $M$.

2. Masalah penempatan karyawan dengan jumlah karyawan sama dengan jumlah pekerjaan, dapat dimodelkan dengan menggunakan graf bipartit lengkap berlabel $G=(X, Y)$, dimana $X$ adalah merupakan himpunan karyawan dan $Y$ adalah merupakan himpunan posisi (pekerjaan). Sisi-sisi yang menghubungkannya adalah menyatakan hubungan antara karyawan dengan posisi (pekerjaan) tersebut. Dalam hal ini aspek yang akan dioptimalkan adalah bobot atau peluang penempatan tiap $X$ karyawan pada $Y$ pekerjaan. Untuk mencari solusi optimal dari penempatan karyawan sama halnya dengan mencari matching sempurna dengan bobot maksimal pada graf bipartit. Dengan menerapkan langkah-langkah pada metode hungarian akan didapatkan solusi optimal dari penempatan karyawan.

\section{Referensi}

[1] Chartrand, G. and Zhang, P. 2009. Chromatic Graph Theory. Chapman \& Hall/CRC Press, Boca Raton, FL.

[2] Deistel, Reinhard. 2005. Graph Theory Electronic edition. Springer-Verlag Heidelberg. New York.

[3] Fournier, Jean-claude. 2009. Graph Theory and Applications with Exercises and Problems. ISTE Ltd, London.

[4] Harris, J.M., Hirst, J.L. and Mossinghoff, M.J., 2008. Combinatorics and Graph Theory. Undergraduate Texts in Mathematics (2nd ed.). Springer.

[5] Munir, Rinaldi. 2009. Matematika Diskrit. Bandung: Informatika.

[6] Rosen, Kenneth H. 1999. Discrete Mathematics and Its Application. McGraw-Hill.

[7] Sutarno, Heri. Piatna, Nanang. Nurjanah. 2003. Matematika Diskrit. Bandung: Universitas Pendidikan Indonesia.

[8] Vasudev C. 2006. Graph Theory with Applications. New Age International, New Delhi.

[9] Wijaya, Adi. 2009. Matematika Diskrit. Bandung: Politeknik Telkom.

[10] Xu, Junming. 2003. Theory and Application of Graphs. Kluwer Academic Publishers, London.

[11] http://www.informatika.org/ rinaldi/Matdis/20082009/Makalah2008/Makalah0809-048.pdf diakses pada tanggal 11 November 2011 pukul 20.23.

[12] http://yuwono.himatif.or.id/download/RISET\%20OPERASIONAL.pdf diakses pada tanggal 10 Maret 2012 pukul 19.35. 